DOI 10.37882/2223-2974.2020.11.03

\title{
О НЕКОТОРЫХ ПРОБЛЕМАХ РЕАЛИЗАЦИИ ПРАВА НА ОСУЩЕСТВЛЕНИЕ ТРУДОВОЙ ДЕЯТЕЛЬНОСТИ ИНОСТРАННЫМИ ГРАЖДАНАМИ
}

\section{ON SOME PROBLEMS OF THE IMPLEMENTATION OF THE RIGHT TO WORK BY FOREIGN CITIZENS}

E. Burtseva

E. Klimova

Summary: The article discusses some of the main problems of the implementation of labor activities by foreign citizens on the territory of the Russian Federation. Currently, the procedure for the employment of foreign citizens is overly complicated, which leads to a violation of the current legislation.

Keywords: foreigner, labor organization, employee, employer, contract, patent, visa, quota.
Бурцева Евгения Валериевна

К.n.н., дочент, ФГБОУ ВО МГУ

имени адмирала Г.И. Невельского

evbur@list.ru

Климова Оксана Михайловна

К.ф.н., старший преподаватель, Владивостокский филиал ФГКОУ ВО «ДВЮИ МВД России»

klimova.oksana1973@mail.ru

Аннотация: В статье рассматриваются некоторые основные проблемы осуществления трудовой деятельности иностранными гражданами на территории Российской Федерации. В настоящее время процедура трудоустройства иностранных граждан чрезмерно усложнена что приводит к нарушению действующего законодательства.

Ключевые слова: иностранец, трудоустройство, работник, работодатель, договор, патент, виза, квота.

Трудовой кодекс Российской Федерации определяет равные возможности для реализации трудовых прав. «Никто не может быть ограничен в трудовых правах и свободах или получать какие-либо преимущества в зависимости от пола, расы, цвета кожи, национальности, языка, происхождения, имущественного, семейного, социального и должностного положения, возраста, места жительства, отношения к религии, убеждений, принадлежности или непринадлежности к общественным объединениям или каким-либо социальным группам, а также от других обстоятельств, не связанных с деловыми качествами работника» [2].

Право свободно трудиться также отражено в ч. 1 ст. 13 ФЗ РФ от 25 июля 2002 г. № 115-Ф3, в которой говорится, что «иностранные граждане пользуются правом свободно распоряжаться своими способностями к труду, выбирать род деятельности и профессию, а также правом на свободное использование своих способностей и имущества для предпринимательской и иной не запрещенной законом экономической деятельности с учетом ограничений, предусмотренных федеральным законом » [5].

В связи с существующими экономическими потребностями государство поставило перед собой задачу привлечения отбора и эффективного использования иностранной рабочей силы.

Правила привлечения иностранных рабочих, деталь- 
но регламентированы российским законодательством. Согласно Федерального закона N 115- Ф3 «О правовом положении иностранных граждан в Российской Федерации» все иностранные граждане, желающие осуществлять трудовую деятельность в России на основании трудовых, гражданско-правовых договоров, а также в качестве индивидуального предпринимателя, обязаны получать разрешение на работу [3].

Существует несколько способов трудоустройства граждан иностранного государства на территории Российской Федерации. Первым можно назвать оформление патента. Условиями, по которым работодатель может привлечь к работе иностранца на основе патента являются: совершеннолетие, законность пересечения границы из страны с безвизовым режимом, пребывание на территории России без ограничений. Устроиться на работу по трудовым патентам могут иностранцы, прибывшие из стран, с которыми у России заключен безвизовый режим. Исключения составляют граждане стран, входящих в список стран Таможенного союза, таковыми являются: Белоруссия, Казахстан, Армения, Киргизия.

Данный способ трудоустройства является наиболее доступным и простым и подразумевает привлечение на работу иностранного гражданина у физического лица - гражданина Российской Федерации. Сегодня для приобретения патента государству вполне достаточно факта уплаты фиксированных платежей. Однако законодательством установлено ограничение по привлечению к работе иностранного гражданина, не указанной в патенте. Таким образом, во время действия патента можно использовать работника только по указанной в ней специальности. При этом если возникла экономическая потребность в работнике с другой квалификацией, то обучение и трудоустройство данного работника, будет не возможно. Вторым вариантом легального трудоустройства иностранца является заключение трудового договора с юридическим лицом. Без выделения квоты работодатель имеет право привлечь специалистов на должности, перечень которых утвержден Приказом Минтруда России от 05.07.2019 N 490бн «Об утверждении перечня профессий (специальностей, должностей) иностранных граждан - квалифицированных специалистов, трудоустраивающихся по имеющейся у них профессии (специальности), на которых квоты на выдачу иностранным гражданам, прибывающим в Российскую Федерацию на основании визы, разрешений на работу не распространяются». В соответствии с данным документом возможно привлечение иностранных работников без квоты по восьмидесяти профессиям. Однако в основном это руководители, инженеры, а также работники творческих профессий.

При внешней привлекательности данного способа, можно выделить ряд проблем. Приглашая на работу высококвалифицированного специалиста, работодатель может обойтись без квоты, однако законодательно он обязан выплачивать заработную плату не ниже двух миллиона рублей в год. Данная сумма является неприемлемой для малого бизнеса.

Кроме того, настоящим законодательством не установлены требования к уровню квалификации работника. Предприниматель, приглашающий на работу иностранного специалиста, самостоятельно оценивает уровень его профессиональных знаний и умений. Таким образом, действительно ли будет трудоустроен специалист с должным уровнем квалификации не известно, так как законом не установлены четкие требования к квалификационной характеристике будущего специалиста. Соответственно мы полагаем что создание единых квалификационных требований решило бы эту проблему.

Самым распространенным вариантом трудоустройства иностранных граждан является получение квоты. Определение потребности государства в тех или иных специалистах при формировании квот осуществляется на основании Приказа Минтруда России от 23.01.2014 N 27н (ред. от 09.10.2019) «Об утверждении Правил определения органами государственной власти субъекта Российской Федерации потребности в привлечении иностранных работников» и сопряжено с рядом проблем. Заявка на выделение квоты должна быть подана с первого рабочего дня января и до первого мая. Таким образом, если появилась экономическая потребность трудоустроить иностранного работника, или предприятие было зарегистрировано во второй половине года то вряд ли это будет возможно сделать официально. Кроме того, заявки о выделении квот могут быть приняты исключительно на уровне субъекта через автоматизированную систему, а заявка, поданная в текущем году, будет автоматически сформирована как заявка на следующий календарный год. Таким образом желание работодателя оформить иностранного рабочего путем подачи заявки в феврале будет удовлетворено только в следующем году.

Выделение квот согласно заявке, происходит с учетом политико-экономической ситуации, а также в зависимости от реализуемых видов деятельности работодателем что порождает еще одну проблему. То есть если работодатель занимается производством сельскохозяйственной продукции, то получить квоту на строителя или повара будет проблематично.

Хочется отметить, что процедура привлечения безвизового иностранного работника сопряжена с рядом сложностей. С того момента, когда будет подана заявка и до момента получения разрешения на въезд в Российскую Федерацию проходит достаточно много времени 
и будет ли актуальным для иностранного работника желание трудоустроиться неизвестно. В данном случае мы солидарны с позицией В. А. Волох, который указывает, что при действующей системе квотирования очень сложно предсказать, будет ли востребован данный работник работодателем после прохождения всей процедуры трудоустройства.

Несмотря на явную экономическую выгоду от привлечения иностранной рабочей силы, оформление и дальнейшее сопровождение иностранца вызывают зна- чительные трудности.

В процессе привлечения иностранных работников работодатель сталкивается с достаточным количеством проблем. Постоянно изменяющееся законодательство, чрезмерно усложненная процедура трудоустройства, работника приезжающего из-за рубежа, большое количество контролирующих органов не редко заставляют отказаться от привлечения иностранной рабочей силы или придумать способы использования иностранных рабочих в обход российского законодательства.

\section{ЛИТЕРАТУРА}

1. Скачкова Г.С. Трудовая деятельность иностранцев в России в контексте миграционной политики Российского государства // Миграционное право. 2013. N 2. C. 9 - 11 // СПС «КонсультантПлюс»

2. Гришанова А.Г., Красинец Е.С. Трудовая миграция и миграционная политика в современном российском обществе // Миграционное право. 2014 . N 1. С. 26 - 31 // СПС «КонсультантПлюс»

3. Трудовой кодекс Российской Федерации от 30.12.2001 N 197-Ф3 (ред. от 31.07.2020) (с изм. и доп., вступ. в силу с 13.08.2020) // СПС «КонсультантПлюс».

4. Конституция Российской Федерации (принята всенародным голосованием 12.12.1993 с изменениями, одобренными в ходе общероссийского голосования 01.07.2020)//СПС «КонсультантПлюс».

5. Федеральный закон от 25.07.02 115-Ф3 N (ред. 31.07.20) «0 правовом положении иностранных граждан в Российской Федерации» // СПС «КонсультантПлюс».

○ Бурцева Евгения Валериевна (evbur@list.ru), Климова Оксана Михайловна (klimova.oksana1973@mail.ru).

Журнал «Современная наука: актуальные проблемы теории и практики»

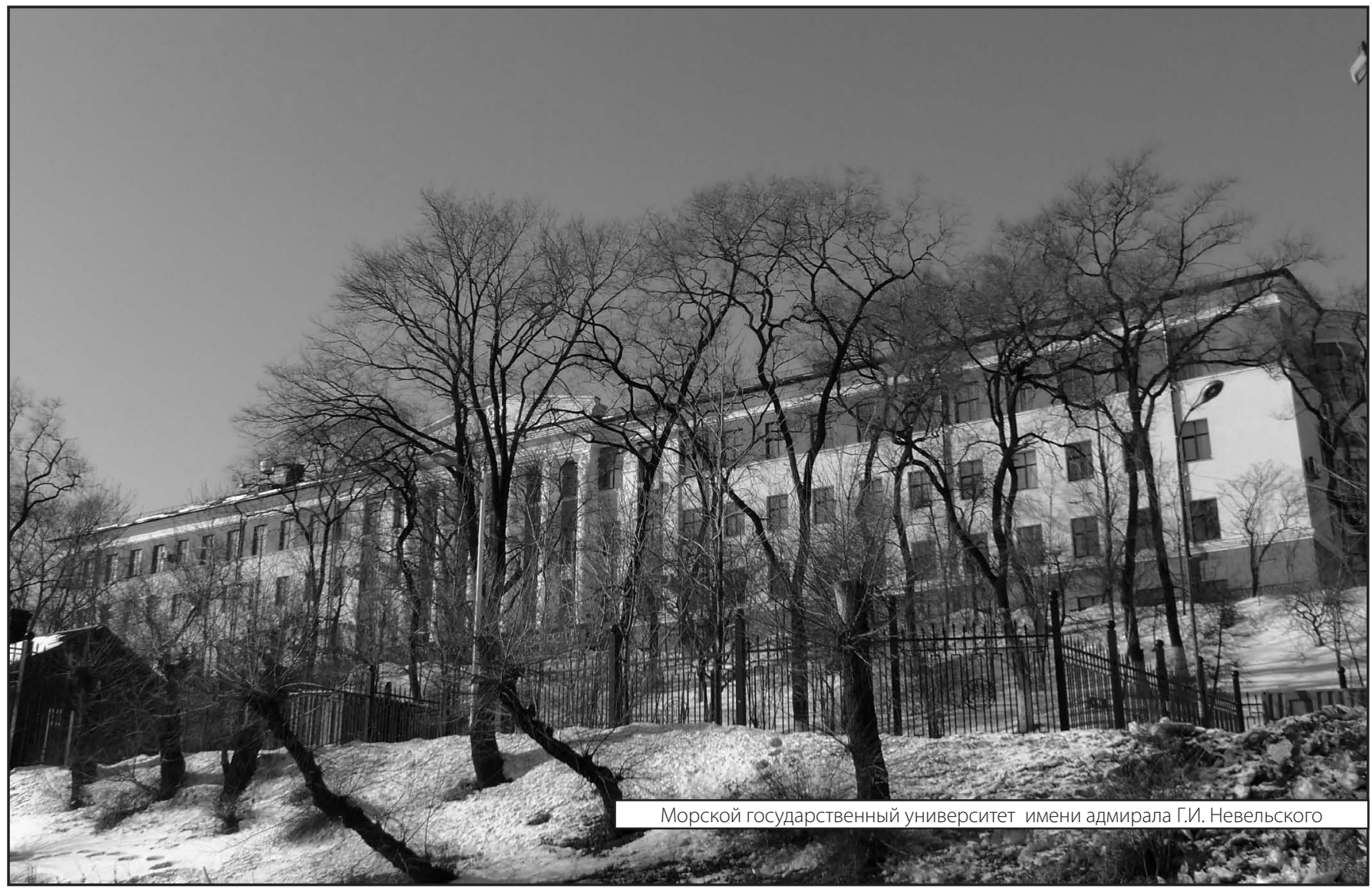

